\title{
KINETIC AND ISOTHERM ANALYSIS OF Cu(II) ADSORPTION ONTO ALMOND SHELL (Prunus dulcis)
}

\author{
ANALIZA KINETYKI I IZOTERM ADSORPCJI Cu(II) \\ NA SKORUPACH MIGDAŁÓW (Prunus dulcis)
}

\begin{abstract}
In the work, adsorption of $\mathrm{Cu}^{2+}$ ions onto almond shell were investigated under different operational conditions. Almond shell was used without any pretreatment prior to the tests. The optimum conditions for

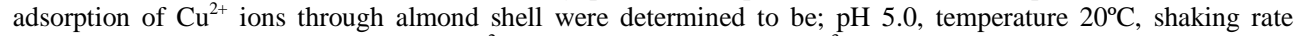
$125 \mathrm{rpm}$, sorbent dose $0.3 \mathrm{~g}$ and initial $\mathrm{Cu}^{2+}$ ion concentration $50 \mathrm{mg} / \mathrm{dm}^{3}$. The equilibrium duration of the system was 60 minutes. The sorption capacities of the sorbents were predicted with the aid of equilibrium and kinetic models. The interactions of peanut shell with metal ions were constituted by SEM, EDX, FT-IR, XRD and AFM. The pseudo-first-order, pseudo-second-order, Weber-Morris, Elovich model and Bangham kinetic models were applied to test the experimental data. The $\mathrm{Cu}^{+2}$ ions adsorption onto almond shell was better defined by the pseudo-second-order kinetic model, for initial $\mathrm{pH}$. The equilibrium data were evaluated using Langmuir, Freundlich, Temkin, D-R and Harkins Jura isotherms. The highest $R^{2}$ value in isotherm studies was obtained from Langmiur isotherm $\left(R^{2}=0.98\right)$ for the inlet concentration.
\end{abstract}

Keywords: adsorption, kinetics, isotherm study, almond shell, characterization sorbent

\section{Introduction}

Contamination of water environment with heavy metals like $\mathrm{Cu}^{2+}$, coming from casting and mining industries, textile, batteries, leather production and electro coatings, may pose serious threats for human health and aquatic organisms [1]. Even in low concentrations, heavy metal ions exhibit very high toxicity and they are non-biodegradable [2]. It has been reported in numerous studies that such heavy metals have high potential for inducing severe damage on human health and natural aquatic environment due to their predisposition to bio-accumulate and permanence [3].

Chemical precipitation, membrane filtering and reverse osmosis methods are widely applied for removal of heavy metals [4]. However, these methods are known to be costly and they do not have high removal effectiveness for metal concentrations especially within $0.01-0.1 \mathrm{~g} / \mathrm{dm}^{3}[5]$.

Adsorption is known to be an effective method for reducing the concentration of pollutants such as organic compounds, metal ions and dissolved dye in wastewater [6].

\footnotetext{
${ }^{1}$ Department of Environmental Engineering, Engineering Faculty, Cumhuriyet University, Kayseri Str., 58140, Sivas, Turkey, phone +9003462191010, email: sayiteryildiz@ gmail.com
} 
Adsorption is the most widely applied process for removal of heavy metals due to its simplicity, practicability and cost efficiency among other removal methods.

Recent studies on adsorption have drawn the attention to waste materials produced by large-scale industrial processes. Such materials are the by-products of industrial materials produced from natural resources such as peat, wood, barley, brown rice, hay, peanut shell, almond shell, nutshell, biomass, soybean, cottonseed meal, bark, sugar beet pulp, leaves, green algae, coconut wastes, wood chips, fertilizer, corn silk, and dried aquatic plants, as well as plant wastes and other industrial products [1,7-9]. All of these materials have been the subject of numerous studies due to their ability to remove trace metals from water. Most of the researches that used adsorbents for organic compounds are based on batch kinetic and batch equilibrium studies $[10,11]$.

Almond shell is commonly known as a waste product. Almond shell is an abundant, cheap and lignocellulosic material. Cell walls of almond shell consist of cellulose, silica, lignin and carbonhydrates that have hydroxyl groups in their structure [12].

In the present study, almond shell was used without any pretreatment prior to the tests. The use of sorbent without any activation treatment as an attempt to reduce the cost of adsorption process constitutes one of the important aspects of the present research. The main objective of the study was to investigate the feasibility of using natural almond shells as adsorbent in removal of $\mathrm{C}$ (II) ions; to evaluate various experimental parameters that affect the adsorption process, including the initial $\mathrm{pH}$ of the aqueous solution, contact time, initial concentration and temperature; to assess the efficacy of various kinetic models (pseudo-first-order, pseudo-second-order, Elovich and intra-particle diffusion models); to determine the applicability of isotherm models (Langmuir, Freundlich, Temkin and Dubinin-Radushkevich); and to specify the thermodynamic feasibility of the adsorption process in accordance with thermodynamic parameters (Gibbs energy $(\Delta G)$, enthalpy $(\Delta H)$ and entropy $(\Delta S))$.

\section{Materials and method}

\section{Preparation of adsorbent and solution}

Almond shell was procured from local market in Turkey and it was used without any pretreatment except washing and sieving for obtaining the desired particle size. Almond shell was washed for a few times with deionized water for removal of impurities on the shell surface, and afterwards it was dried in oven for a period of 24 hours at $105^{\circ} \mathrm{C}$. Dried almond shell specimens were then ground and sieved with $0.30 \mathrm{~mm}$ mesh size prior to the experiments. In addition to the use of deionized water, all used chemicals were chosen among analytical grade reagents of highest quality. The physical and chemical properties of almond shell are given in Table 1 [13].

Physical and chemical properties of almond shell

\begin{tabular}{|c|c|}
\hline Hemicellulose & $35.160 \%$ \\
\hline Cellulose & $29.991 \%$ \\
\hline Lignin & $30.015 \%$ \\
\hline Ash & $0.760 \%$ \\
\hline C & $48.170 \%$ \\
\hline H & $5.893 \%$ \\
\hline O & $45.937 \%$ \\
\hline
\end{tabular}




\begin{tabular}{|c|c|}
\hline Extractive content & $5.074 \%$ \\
\hline Surface area & $10.95 \mathrm{~m}^{2} \mathrm{~g}^{-1}$ \\
\hline Apparent density & $1.07 \mathrm{~g} \mathrm{~cm}^{-3}$ \\
\hline Porosity & $22.11 \%$ \\
\hline Pore diameter (mean) & $0.075 \mu \mathrm{m}$ \\
\hline Functional groups & \\
\hline O-H & $3440 \mathrm{~cm}^{-1}$ \\
\hline C-H (aromatic and aliphatic) & $2904 \mathrm{~cm}^{-1}$ \\
\hline C=O & $1740,1650 \mathrm{~cm}^{-1}$ \\
\hline C=C (aromatic) & $1600,1507 \mathrm{~cm}^{-1}$ \\
\hline C-H & $1466,1377 \mathrm{~cm}^{-1}$ \\
\hline C-O & $1161 \mathrm{~cm}^{-1}$ \\
\hline
\end{tabular}

$\mathrm{Cu}^{+2}$ solution was prepared in $1 \mathrm{dm}^{3}$ with $1000 \mathrm{mg} / \mathrm{dm}^{3}$ concentration, with addition of the required amount of copper sulphate $\left(\mathrm{CuSO}_{4} \cdot 5 \mathrm{H}_{2} \mathrm{O}\right)$. Metal ion concentrations with different concentrations were prepared by diluting required amounts from the stock solution.

\section{Test and analysis method}

Adsorption of $\mathrm{Cu}^{2+}$ from aqueous solution onto almond shells was investigated using batch equilibrium techniques. The tests were conducted by inclusion of $100 \mathrm{~cm}^{3}$ copper solution and biosorbent in $250 \mathrm{~cm}^{3}$ Erlenmeyer flasks. $0.3 \mathrm{~g}$ almond shell was included in the $100 \mathrm{~cm}^{3}$ solution with the required $\mathrm{Cu}^{2+}$ concentration. The batch units were agitated in an orbital incubator shaker (Gerhardt) for a contact time varied in the range 0-60 min at a speed of $125 \mathrm{rpm}$ at $25^{\circ} \mathrm{C}$. The time at which sorbent added to nickel solution is assumed to be $t=0$ and analyses were performed at certain intervals. Free $\mathrm{Ni}^{2+}$ ions were read in samples to find out analyzed in a Merck NOVA60 spectrophotometer. The effect of experimental parameters such as initial $\mathrm{Cu}^{2+}$ ion concentration $\left(5-100 \mathrm{mg} / \mathrm{dm}^{3}\right)$, $\mathrm{pH}(2.0-7.0)$, adsorbent dosage $\left(0.1-1.0 \mathrm{~g} / \mathrm{dm}^{3}\right)$ and temperature $\left(25-55^{\circ} \mathrm{C}\right)$ was examined. The initial $\mathrm{pH}$ of solutions were adjusted using $\mathrm{H}_{2} \mathrm{SO}_{4}$ and $\mathrm{NaOH}$ solutions.

Wise Shake (SHO-2D) and shaking incubator, capable of operating with constant shaking speed and temperature, were used during the research. All $\mathrm{pH}$ readings were performed using a Thermo Orion - STARA2145 brand $\mathrm{pH}$ meter.

The biosorption capacity $q_{e}$ (Eq. (1)), used in biosorption studies, and percent removal efficiency $(E) \%$ (Eq. (2)) were calculated using the following equations:

$$
\begin{aligned}
q_{e} & =\frac{V \cdot\left(C_{o}-C_{e}\right)}{x} \\
(E) \% & =\frac{\left(C_{o}-C_{e}\right)}{C o} \cdot 100
\end{aligned}
$$

where $x$ is the adsorbent amount $[\mathrm{g}] ; V$ is the solution's volume $\left[\mathrm{cm}^{3}\right] ; C_{o}$ is the initial concentration $\left[\mathrm{mg} / \mathrm{dm}^{3}\right]$; and $C_{e}$ is the final concentration of the solution $\left[\mathrm{mg} / \mathrm{dm}^{3}\right]$.

Each sorption experiment was performed three times and average values obtained from the samples were presented. Additionally, a blank sample was used to compare the results throughout all batch procedures. The presented results are the mean values obtained from the experiments, standard deviation $(\leq 4 \%)$ and error bars are shown in the figures. 


\section{Results and discussion}

\section{Characterization}

FT-IR spectrum of almond shells was used to determine the frequency deviation of the functional groups before and after the copper adsorption. As shown in Figure 1, the spectra were measured within $400-4000 \mathrm{~cm}^{-1}$ range.


Fig. 1. FTIR spectra: a) before and b) after adsorption 
a)

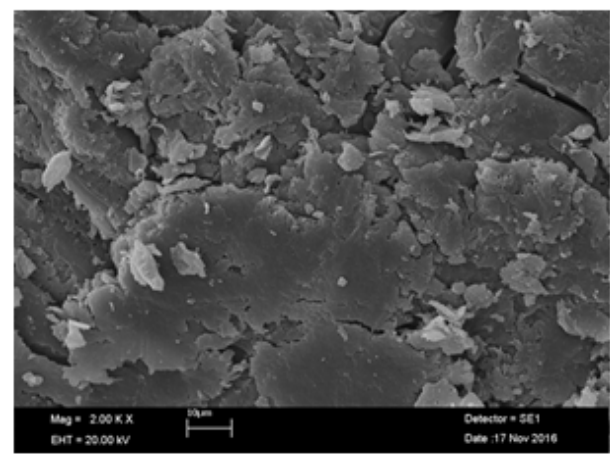

b)

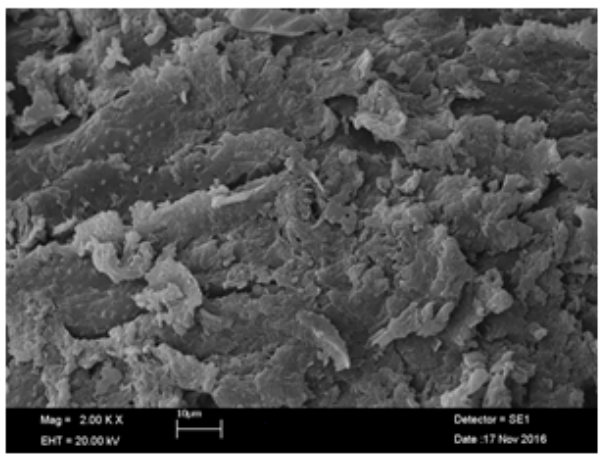

Fig. 2. SEM image of almond shell: a) before and b) after adsorption

a)
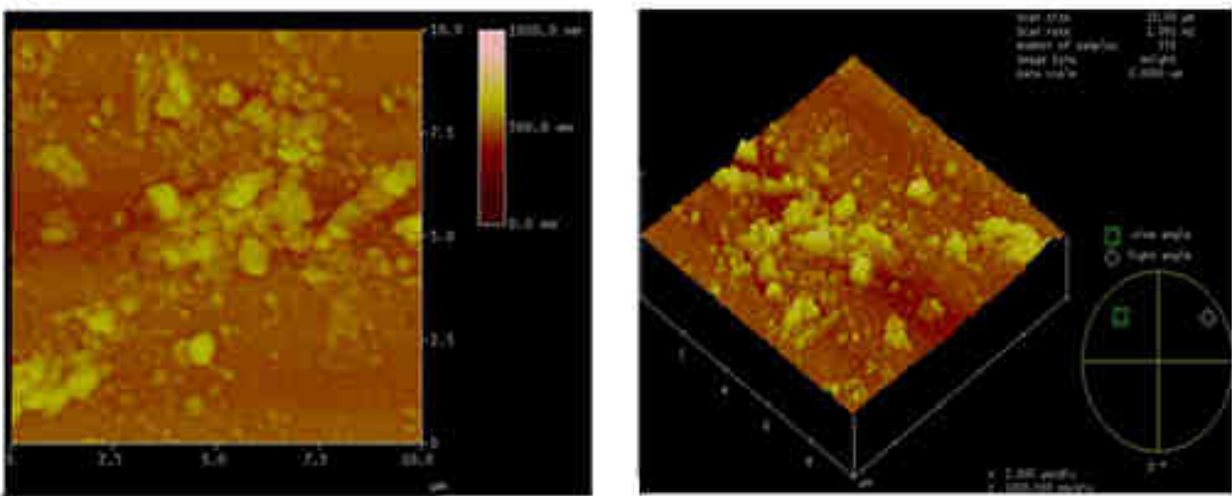

b)
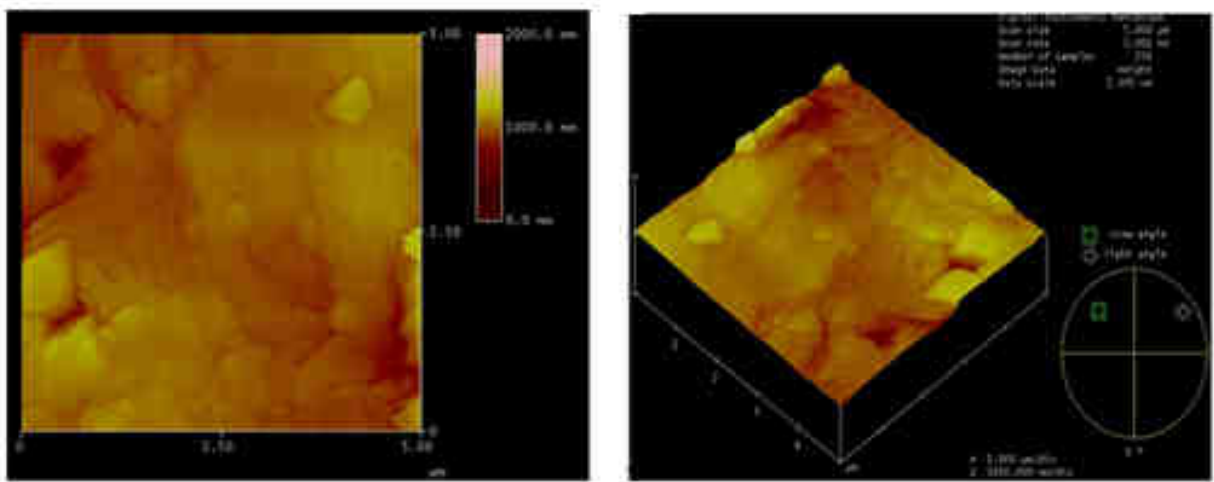

Fig. 3. AFM image of almond: a) before and $b$ ) after adsorption 
The peak points, representing the wide adsorption bands, were observed at 3296.15, 2892.5, 1633.44, 1482.10, 1018.13, and $556.89 \mathrm{~cm}^{-1}$. The band at $3296.15 \mathrm{~cm}^{-1}$ results from stretching vibration $(\mathrm{O}-\mathrm{H})$. The band at $2892.5 \mathrm{~cm}^{-1}$, may be an indication of aromatic and aliphatic stretching vibration. The band at $1633.44 \mathrm{~cm}^{-1}$ results from carbonyl group stretching, and the one at $1482.10 \mathrm{~cm}^{-1}$ results from $\mathrm{C}-\mathrm{H}$ deformation vibration. The band at $1018.13 \mathrm{~cm}^{-1}$ represents $\mathrm{C}-\mathrm{O}$ stretching vibration and the band at $556.89 \mathrm{~cm}^{-1}$ may correspond to $\mathrm{SiO}-\mathrm{H}$ vibration [14].

SEM analysis is widely applied to examine the morphological properties of adsorbent substances. SEM images of almond shell specimens before and after absorption are given in Figure 2. Presence of suitable conditions for adsorption of $\mathrm{Cu}$ ion into the pores is evident in the images. This situation is also clearly indicated in the AFM images in Figure 3. Roughness of the sorbent surface is higher before adsorption (Fig. 3a) whereas the porous structure is filled after adsorption resulting in a smoother structure (Fig. 3b).

Sharp asperities of almond shell are shown in the XRD spectrum in Figure 4. Similar peaks were available at $15^{\circ}$ and $21^{\circ}$ on the almond shell. This indicates that no structural deterioration occurred during adsorption.
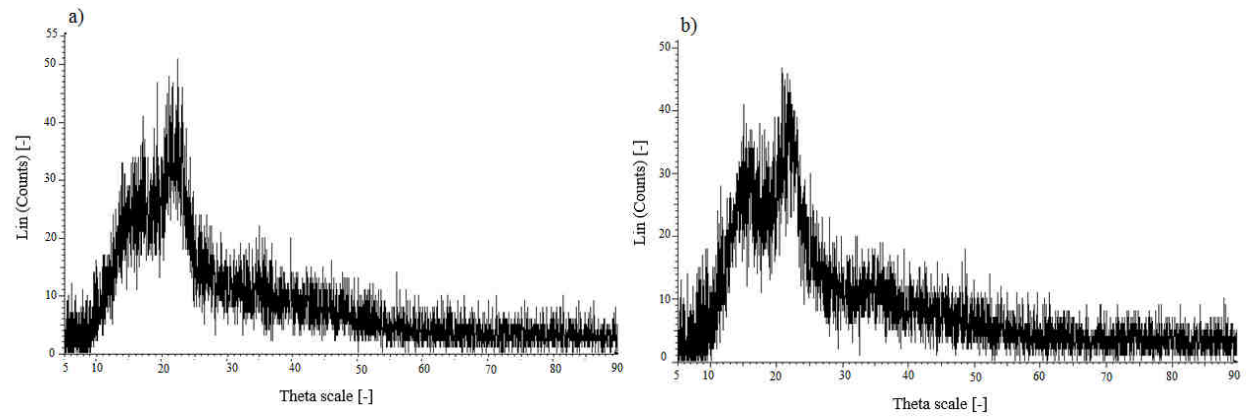

Fig. 4. XRD: a) before and b) after adsorption

\section{Adsorption experiments}

The contact time of adsorption of copper into almond shell under the specified conditions $\left(T=25^{\circ} \mathrm{C}, C_{o}=50 \mathrm{mg} / \mathrm{dm}^{3}, x=0.3 \mathrm{~g}, \mathrm{pH}=5\right)$ was investigated for $0-150$ minutes time interval. Removal efficiency [\%] and the $q_{e}$ are given in Figure 5. As seen in the figure, a period of 60 minutes was found to be sufficient for removal of $\mathrm{Cu}$ (II) with almond shell. Some of the previous researches similarly reported 60 minutes contact time for heavy metal removal with almond shell [15]; in other studies lower [16, 17] and higher $[14,18]$ contact times were also reported.

\section{Effect of varying $\mathrm{pH}$}

The $\mathrm{pH}$ value of an aqueous solution is an important control parameter in the adsorption process. The experiments were carried out within 2-7 pH interval (Fig. 6). Over $\mathrm{pH} 6, \mathrm{Cu}$ started to precipitate as $\mathrm{Cu}(\mathrm{OH})_{2}$. This is verified by the speciation diagram given in Figure 7 [19]. Similar observations were reported in previous studies [20-22]. Under $\mathrm{pH}=6$, the dominant copper specie was $\mathrm{Cu}(\mathrm{II})$ which was normally included in the adsorption process. The adsorbed amount of copper gradually increased from 1.57 to 
$6.07 \mathrm{mg} / \mathrm{g}$ as the $\mathrm{pH}$ value increased from 2 to 6 . Copper adsorption was found to be significantly low at very low $\mathrm{pH}$ values due to the competition between $\mathrm{H}_{3} \mathrm{O}^{+}$and $\mathrm{Cu}$ (II) ions. $\mathrm{H}^{+}$ions react with anionic functional groups on almond shell surface, thus leading to limitation of the number of binding locations available for adsorption of $\mathrm{Cu}(\mathrm{II})$.

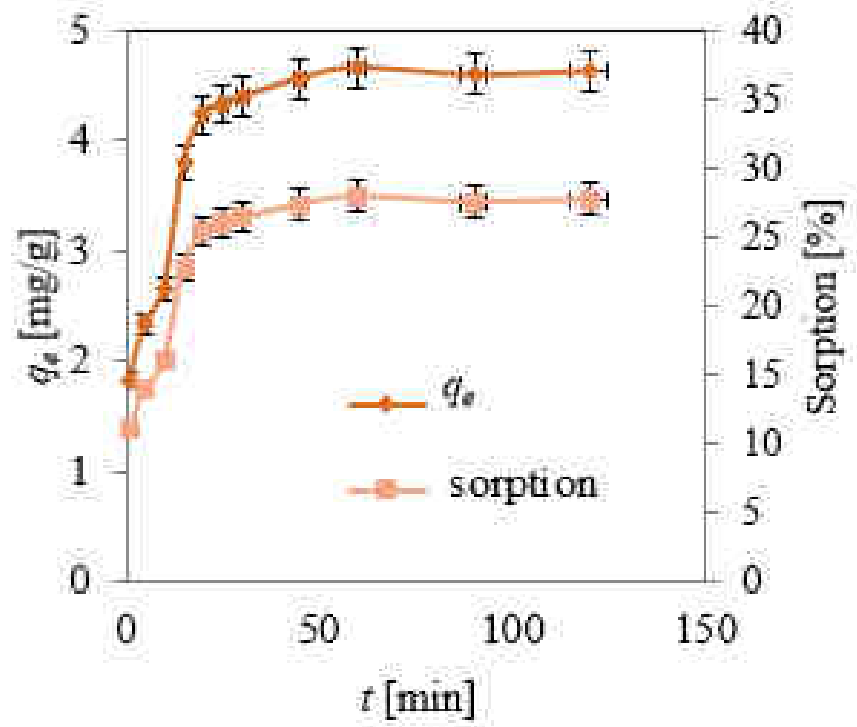

Fig. 5. Change of adsorption capacity with varying contact time

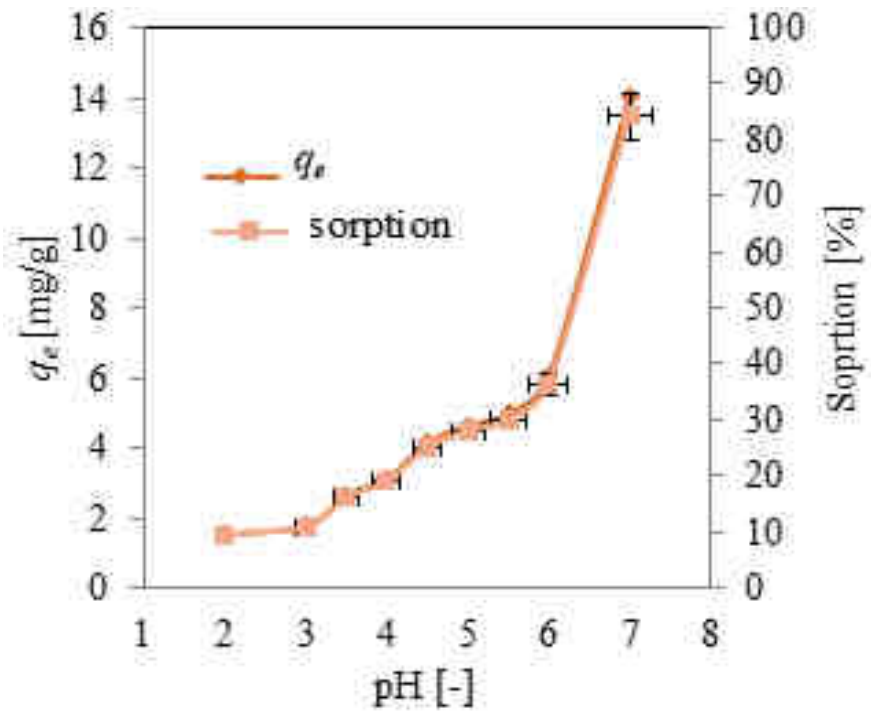

Fig. 6. Efficiencies for different $\mathrm{pH}$ values 


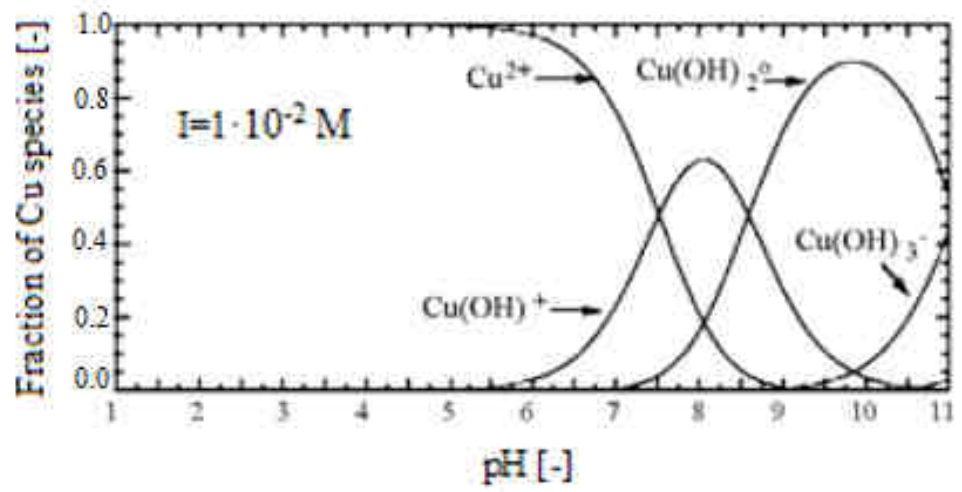

Fig. 7. Distribution of $\mathrm{Cu}(\mathrm{II})$ species as a function of $\mathrm{pH}$

\section{Effect of sorbent amount}

Analyses were performed within $0.1-1 \mathrm{~g} / 100 \mathrm{~cm}^{3}$ interval to investigate the effect of sorbent amount on biosorption $(0.1,0.2,0.3,0.4,0.5,0.7,1 \mathrm{~g})$. The effect of sorbent amount on adsorption is shown in Figure 8 . The highest $q_{e}$ value was obtained as $4.70 \mathrm{mg} / \mathrm{g}$ during the $0.5 \mathrm{~g}$ sorbent usage, whereas the highest removal efficiency was found as $64 \%$ during $1 \mathrm{~g}$ sorbent usage.

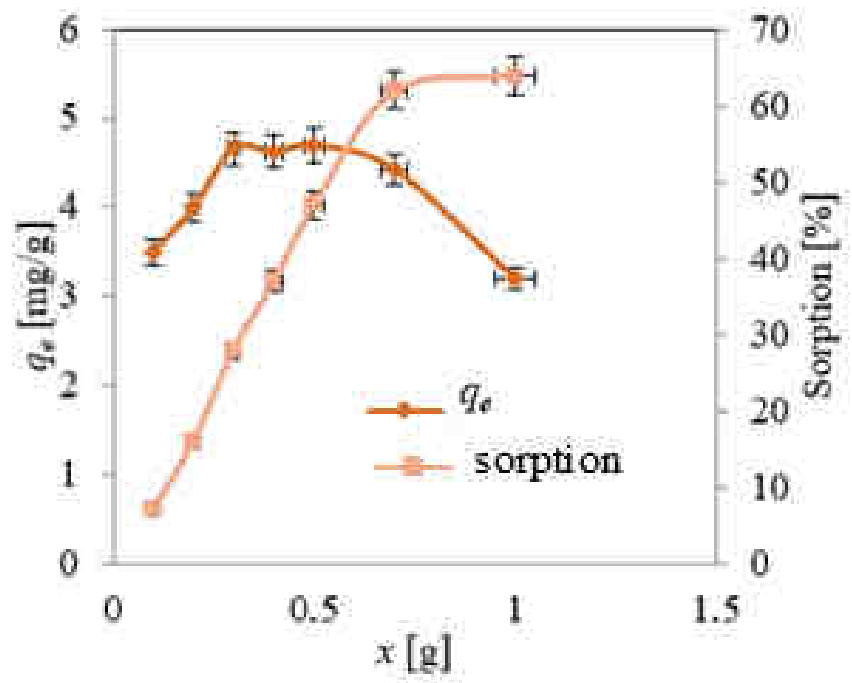

Fig. 8. The effect of sorbent amount on adsorption

As seen in Figure $8 q_{e}$ started to increase with increasing sorbent amount, however after a certain point $q_{e}$ value decreased despite the increase in sorbent amount. Such decrease in the adsorbed amount in spite of the increase in adsorbent dosage can be attributed to the electrostatic interactions, binding site interactions, and reduced mixing at 
higher adsorbent densities. Also, the decrease in sorption capacity is attributed to the increase in interface area with dilution of the suspension [23].

\section{Effect of initial metal concentration}

The effects of initial copper concentration on adsorption efficiency and capacity are shown in Figure 9. During the research metal concentration varied within $5-100 \mathrm{mg} / \mathrm{dm}^{3}$ interval. The highest $q_{e}$ value was found as $5.60 \mathrm{mg} / \mathrm{g}$ for $100 \mathrm{mg} / \mathrm{dm}^{3} \mathrm{Cu}$ (II) concentration and the highest removal efficiency was found as $64 \%$ for $5 \mathrm{mg} / \mathrm{dm}^{3} \mathrm{Cu}$ (II) concentration. As seen in Figure 9, copper retention of almond shell depends on the initial concentration and it increases with the increase in availability of metal ions in the test solutions. When the sorbent amount is constant, an increase in the amount of metal ions requires a higher driving force for removal of the ions from aqueous phase to sorbent surface, resulting in an increased probability of interaction between metal ions and active binding areas [24].

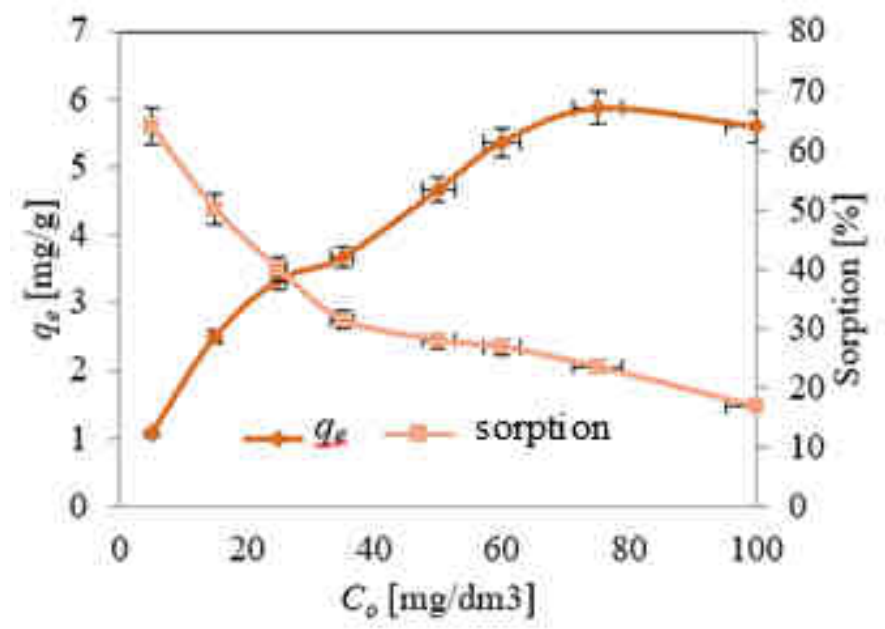

Fig. 9. The effect of initial metal concentration

\section{Effect of temperature}

The experiments were carried out at $20-55^{\circ} \mathrm{C}$ interval for investigation of the effect of temperature on adsorption. Some researchers reported an increase [25, 26] some reported a decrease [27-29] in adsorption capacity depending on the temperature and some [11] reported that the adsorption capacity did not change with changing temperature. As seen in Figure 10, temperature did not have a significant effect on the adsorption capacity in the present study. 


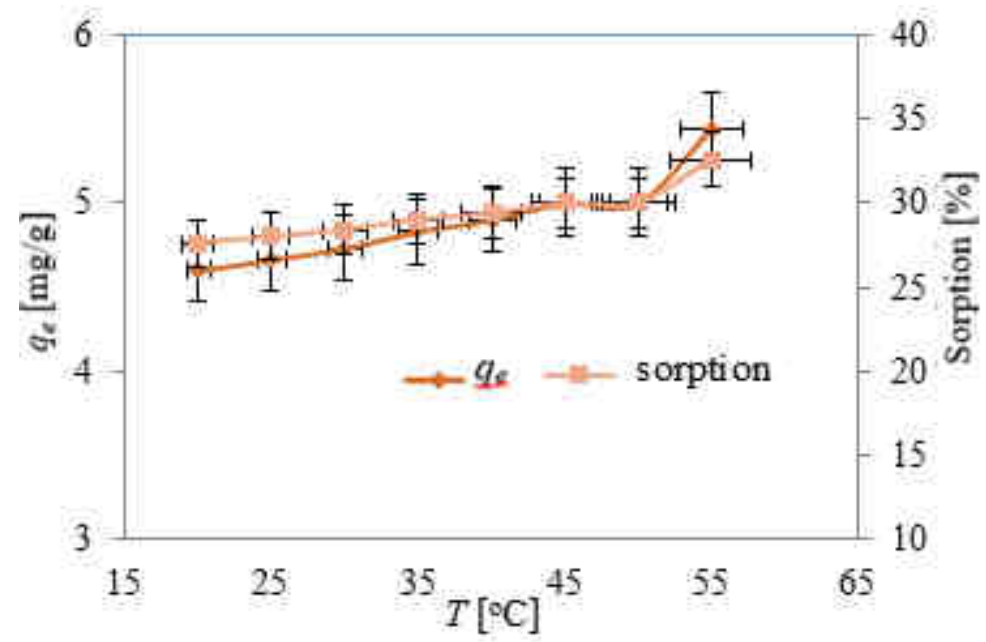

Fig. 10. Effect of temperature on adsorption

\section{Kinetic studies}

\section{Pseudo-first-order kinetic equation}

This equation is also known as Lagergren equation (Eq. (3)) and it is stated with the following expression [30, 31]:

$$
\log \left(q_{e}-q\right)=\log q_{e}-\frac{k_{\text {ads.1 }}}{2.303} \cdot t
$$

here, $q$ is the amount of substance adsorbed at any given time $t[\mathrm{mg} / \mathrm{g}]$, and $k_{a d s, 1}\left[\mathrm{~min}^{-1}\right]$ is the adsorption rate constant. When $\log \left(q_{e}-q\right)$ values, corresponding to $t$ values, are graphed, adsorption rate constant is obtained from the slope of the resultant curve, and the amount of substance adsorbed at the time of equilibrium is obtained from the interception value.

Equilibrium adsorption capacity must be known for applicability of Lagergren equation on experimental data. In some cases where $q_{e}$ is not known (or specified), the adsorption phenomenon is likely too slow to be measured. Also, $q_{e}$ must be higher than $q$, which represents the amount of substance adsorbed at any given time [30].

\section{Pseudo-second-order kinetic equation}

In many adsorption phenomena, Lagergren first order rate equation is not applied for all time intervals until the state of equilibrium is achieved and it generally fits well with the first 20-30 minutes of the equilibrium time. However, pseudo-second-order rate equation (Ho-McKay equation) can be applied for the whole state of equilibrium.

According to pseudo-second-order rate equation, adsorption capacity is in direct proportional to the number of active regions on the adsorbent, and kinetic rate law is expressed with equation [32]:

$$
\frac{t}{q}=\frac{1}{k_{a d s, 2} q_{e}^{2}}+\frac{1}{q_{e}} t
$$


here, $k_{a d s, 2}$ is the adsorption rate constant $[\mathrm{g} / \mathrm{mg} \cdot \mathrm{min}]$. When $t / q$ values, corresponding to $T$ values, are graphed, equilibrium adsorption capacity is obtained from the resultant curve, and adsorption rate constant is obtained from the cut-off values.

\section{Intra-particle diffusion equation}

In bio-sorption method, intra-particle diffusion kinetic model was first introduced by Weber and Morris [33, 34].

$$
q=k_{p} t^{0.5}+C
$$

here; $k_{p}$ denotes the intra-particle diffusion constant $\left[\mathrm{mg} \cdot \min ^{0.5} / \mathrm{g}\right]$. When a $q$ versus $t^{0.5}$ graph is plotted, linearity of the curve indicates that intra-particle diffusion takes place within the bio-sorption system. In addition, if the curve in the graph coincides with the origin, this indicates that diffusion is the rate-determining step. If the curve is not coincident with the origin, this indicates that diffusion occurs gradually in a laminated form and that it does not alone correspond to a rate-determining step. $C$ values give an opinion about the thickness of the boundary layer (for instance, the thickness of the boundary layer is as high as the $C$ value) [35].

\section{Elovich Equation}

Elovich equation (Eq. (6)) is a useful model for describing chemical sorption and it is compatible with heterogeneous systems [36].

$$
q_{t}=\frac{1}{\beta} \ln (\alpha \beta)+\frac{1}{\beta} \ln t
$$

here $\alpha$ is the initial adsorption rate $[\mathrm{mg} / \mathrm{g} \cdot \min ]$ and $\beta$ is desorption rate constant $[\mathrm{g} / \mathrm{mg}]$.

\section{Bangham Equation}

By application of Bangham equation (Eq. (7)) on bio-sorption kinetics data, it is possible to check whether pore diffusion is the only rate-determining step [37]

$$
\log \left[\log \left(\frac{C_{0}}{C_{0}-q_{t} m}\right)\right]=\log \left(\frac{k_{0} m}{2.303 V}\right)+\sigma \log (t)
$$

here: $k_{0}$ - equilibrium binding constant $\left[\mathrm{dm}^{3} / \mathrm{g}\right], \sigma$ - Bangham's constant, $m$ - adsorbent amount $[\mathrm{g}], V$ - sample volume $\left[\mathrm{dm}^{3}\right]$.

\section{Evaluation of kinetics results}

Kinetic experiments were performed at $\mathrm{pH} 2-3-4-5-6$ for 1-60 min periods. Pseudo-first-order (Fig. 11a), pseudo-second-order kinetic models (Fig. 11b), Elovich model (Fig. 11c), Bangham kinetic models (Fig. 11d) and inter-particle diffusion model (Fig. 11e) were applied on the obtained kinetics data. Lagergren rate constants $k_{a d s, 1}\left[\mathrm{~min}^{-1}\right]$, $k_{\text {ads }, 2}[\mathrm{~g} / \mathrm{mg} \cdot \mathrm{dk}]$ rate constants in Ho-McKay equation, intra-particle diffusion constants $k_{p}\left[\mathrm{mg} / \mathrm{g} \cdot \mathrm{min}^{0.5}\right]$, desorption rate constants $\beta[\mathrm{g} / \mathrm{mg}]$ and initial adsorption rates $\alpha[\mathrm{mg} / \mathrm{g} \cdot \mathrm{min}]$ in Elovich equation, as well as desorption $\sigma$ constants and equilibrium binding constants $k_{0}\left[\mathrm{dm}^{3} / \mathrm{g}\right]$ in Bangham equation were calculated using the graphs of the kinetic models (Table 2). 
a)

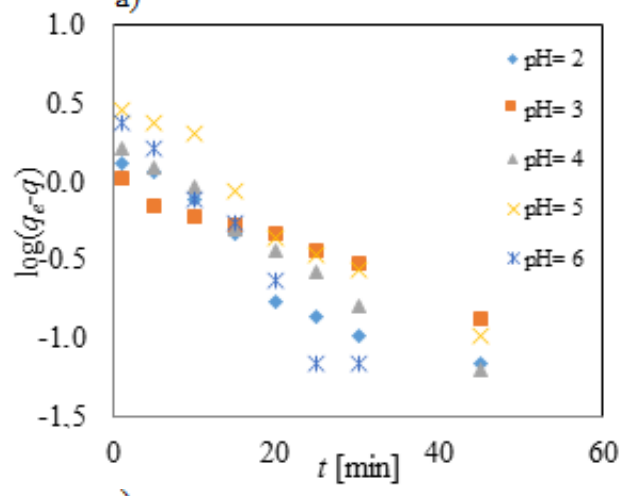

c)

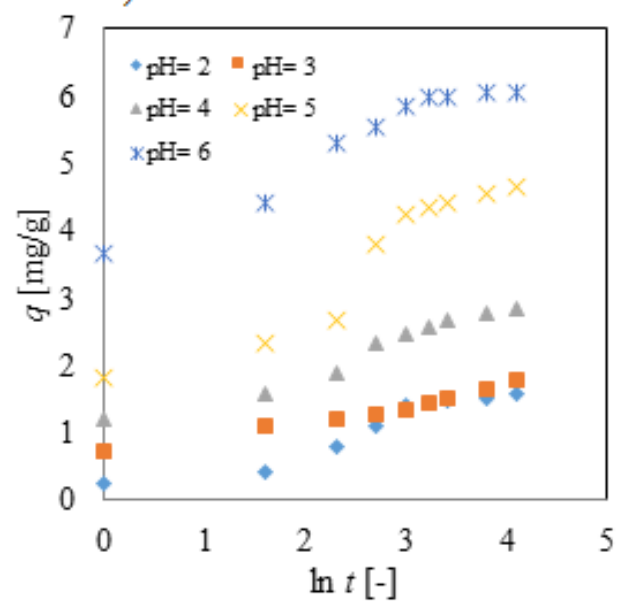

b)


e)

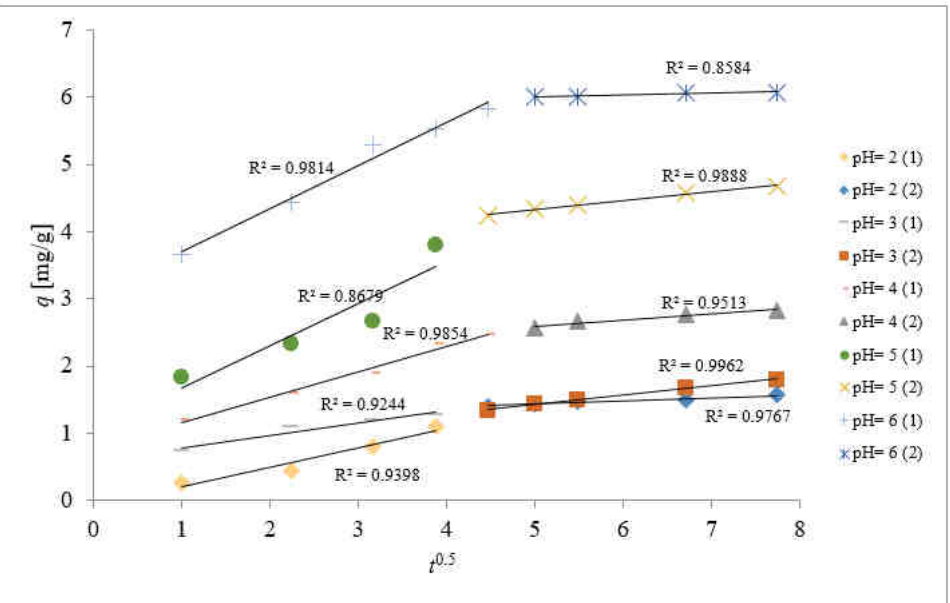

Fig. 11. a) Lagergren graph, b) Ho-McKay graph, c) Elovich graph, d) Bangham graph, e) Weber and Morris graph 
Kinetic constant

\begin{tabular}{|c|c|c|c|c|c|c|c|c|c|c|c|c|c|}
\hline \multirow{3}{*}{ pH } & \multirow{3}{*}{$\begin{array}{l}q_{e}(\exp ) \\
{[\mathrm{mg} / \mathrm{g}]}\end{array}$} & \multirow{2}{*}{\multicolumn{3}{|c|}{ Pseudo-first-order }} & \multirow{2}{*}{\multicolumn{3}{|c|}{ Pseudo-second-order }} & \multicolumn{6}{|c|}{ Weber-Morris } \\
\hline & & & & & & & & \multicolumn{3}{|c|}{-I- } & \multicolumn{3}{|c|}{-II- } \\
\hline & & $k_{1}$ & $q_{e}$ & $R^{2}$ & $k_{2}$ & $q_{e}$ & $R^{2}$ & $k_{i d}$ & $C$ & $R^{2}$ & $k_{i d}$ & $C$ & $R^{2}$ \\
\hline 2 & 1.57 & 0.014 & 1.30 & 0.90 & 0.05 & 1.87 & 0.96 & 0.292 & 0.099 & 0.94 & 0.04 & 1.193 & 0.97 \\
\hline 3 & 1.80 & 0.008 & 1.00 & 0.97 & 0.09 & 1.86 & 0.98 & 0.184 & 0.602 & 0.92 & 0.14 & 0.724 & 0.99 \\
\hline 4 & 3.17 & 0.014 & 1.74 & 0.99 & 0.08 & 3.00 & 0.99 & 0.378 & 0.787 & 0.98 & 0.09 & 2.136 & 0.95 \\
\hline 5 & 4.67 & 0.015 & 3.15 & 0.96 & 0.04 & 5.05 & 0,99 & 0.626 & 1.050 & 0.91 & 0.13 & 3.669 & 0.98 \\
\hline \multirow[t]{3}{*}{6} & 6.07 & 0.025 & 3.02 & 0.97 & 0.11 & 6.23 & 0.99 & 0.642 & 3.062 & 0.98 & 0.02 & 5.854 & 0.85 \\
\hline & & \multicolumn{3}{|c|}{ Elovich } & \multicolumn{3}{|c|}{ Bangham } & & & & & & \\
\hline & & $\boldsymbol{\beta}$ & $\alpha$ & $R^{2}$ & $\sigma$ & $K_{o} \cdot 10^{-4}$ & $\mathbf{R}^{2}$ & & & & & & \\
\hline 2 & 1.57 & 2.686 & 0.49 & 0.90 & 0.49 & 1.2 & 0.93 & & & & & & \\
\hline 3 & 1.80 & 4.060 & 3.84 & 0.95 & 0.21 & 3.4 & 0.98 & & & & & & \\
\hline 4 & 3.17 & 2.263 & 5.02 & 0.95 & 0.23 & 5.5 & 0.97 & & & & & & \\
\hline 5 & 4.67 & 1.238 & 5.06 & 0.89 & 0.26 & 8.0 & 0.91 & & & & & & \\
\hline 6 & 6.07 & 1.523 & 176 & 0.94 & 0.13 & 17.4 & 0.94 & & & & & & \\
\hline
\end{tabular}

As seen in Table 2, high $R^{2}$ values were obtained for all models. The highest $R^{2}$ value, 0.99, was obtained for pseudo-second-order kinetic model. Also, when compared with pseudo-first-order model, in pseudo-second-order kinetic model, theoretical $q_{d}$ values were found to be closer to the experimental $q_{d}$ values. As a result, adsorption of copper with almond shell was found to conform to pseudo second order kinetic model. Similar kinetic behaviors for biosorption of heavy metal ions were reported in previous studies [38-40].

Kinetic models such as intra-particle diffusion model and Elovich equation demonstrate an important role of the pore diffusion process in the adsorption mechanism. As seen in Figure 11e the copper adsorption on almond shell coincides with the origin for all $\mathrm{pH}$ values and it occurs in two steps. The rate constants for two resultant steps were in the order $k_{p 1}>k_{p 2}$, and the $C$ values at each step increased with increasing $\mathrm{pH}$. This is an indication of increased boundary layer thickness with increasing $\mathrm{pH}$, which in turn results in a decrease in the diffusion rate. The first and the second linear sections can be respectively attributed to the external mass transfer and intra particle diffusion mechanisms $[41,42]$.

As seen in Table 2, Bangham equation yielded a fine linear $\left(R^{2}>0.92\right)$ value for removal of copper with almond shell, which indicates that there is no single rate control step for diffusion of the heavy metal into the sorbent pores [43].

\section{Adsorption isotherms}

The graph that associates the amount of substance adsorbed at constant temperature with the unabsorbed substance concentration in the solution, is called as the adsorption isotherm [44]. Isotherm graph shows the equilibrium conditions under constant temperature [45]. An adsorption process can be best understood by use of isotherms [46]. Information on the affinity between the adsorbent-adsorbate, adsorption capacity of the adsorbent, surface area, porosity and adsorption heat can be obtained from adsorption isotherms.

\section{Langmuir adsorption isotherm}

According to Langmuir adsorption isotherm; adsorbent's surface is homogeneous in terms of adsorption capacity. In other words, adsorbent surface has a number of active 
adsorption regions. Maximum one molecule is adsorbed at each adsorption region. Accordingly, Langmuir isotherm is only valid for single layer adsorption [44]. In addition, no interaction occurs among the adsorbed molecules and adsorption occurs with the same mechanism on all adsorption regions of the surface, that is, the absorbed units have identical activation energies [47]. Langmuir isotherm equation is the following:

$$
C_{e} / q_{e}=1 / q_{m} b+1 / q_{m} \cdot C_{e}
$$

here, $q_{m}$ is a constant related with the single layer adsorption capacity of adsorbent and $b$ is a constant for adsorption energy [48]. High $q_{m}$ values is an indication of higher adsorption capacities and accordingly the adsorbent has a big surface area. Constant $b$ is dependent on temperature and it is proportional to adsorption heat.

\section{Freundlich adsorption isotherm}

Adsorbent surface is heterogeneous in terms of adsorption regions and energy. That is, the adsorbed amount of substance increases with increasing concentration of the adsorbed substance. In Freundlich isotherm, there is an exponential relation between the adsorbed amount and the equilibrium concentration [49]:

$$
q_{e}=k \cdot C_{e}{ }^{1 / n}
$$

here, $k$ and $n$ denote Freundlich constants respectively related with adsorption capacity and adsorption intensity. $k$ is proportional to the adsorption capability of the adsorbent, and $n$ is proportional to the adsorption tendency of the adsorbed substance [50].

\section{Dubinin-Radushkevich (D-R) adsorption isotherm}

This isotherm was developed by Dubinin-Radushkevich and it is widely applied in defining the adsorption of gases and steam onto micro-porous solids. In cases where liquid phase adsorption occurs, adsorption energy is calculated in accordance with D-R equation. $\mathrm{D}-\mathrm{R}$ isotherm model provides information as to whether the adsorption is chemical or physical. The linear form of D-R isotherm model is expressed with equation [51]:

$$
\ln q_{e}=\ln q_{m}-\beta \cdot \varepsilon^{2}
$$

here, $\beta\left[\mathrm{mol}^{2} / \mathrm{J}^{2}\right]$ is the constant related with average free energy per 1 mole of substance and $\varepsilon$ is Polanyi potential $[\mathrm{kJ} / \mathrm{mol}]$, which is calculated with the following equation:

$$
\varepsilon=R \cdot T \cdot \ln \left(1+\frac{1}{C_{e}}\right)
$$

where $R$ is the ideal gas constant $[8.314 \mathrm{~J} / \mathrm{mol} \cdot \mathrm{K}]$ and $T$ is the absolute temperature $[\mathrm{K}]$. In a plot of $\varepsilon^{2}$ versus $\ln q_{e}$ values, a line with the slope of - $\beta$ and with interception value of $\ln q_{m}$ is obtained. $\beta$ gives information on the average free energy of the adsorption per one molecule of the adsorbed substance. The relation between them is given in following equation [52]:

$$
E=\frac{1}{\sqrt{2 \beta}}
$$

This parameter also gives information as to whether a chemical ion exchange or a physical adsorption mechanism is effective. If the magnitude of $E$ value is between $8-16 \mathrm{~kJ} / \mathrm{mol}$, it is a chemical ion variation, and if it is lower than $8 \mathrm{~kJ} / \mathrm{mol}$ it is a physical adsorption mechanism [53]. 


\section{Temkin adsorption isotherm}

Temkin adsorption isotherm gives information about the adsorption heat and the interactions between adsorbent-adsorbed substances as expressed in [54]:

$$
q_{e}=B_{1} \ln K_{T}+B_{1} \ln C_{e}
$$

where: $B_{i}$ is a constant $(R T / b)$ for the adsorption heat and $K_{T}$ is the equilibrium binding constant $\left[\mathrm{dm}^{3} / \mathrm{g}\right]$. In Temkin Model it is assumed that, the adsorption heat (as a function of temperature) of all molecules in the layer, will exhibit a linear behavior rather than logarithmic within the covered region [55]. An increase in Temkin isotherm constants shows that the adsorption heat $\left(B_{1}\right)$ increases with increasing temperature, thus indicating that the adsorption is endothermic [56].

\section{Harkins-Jura adsorption isotherm}

Harkins-Jura isotherm defines a multi-layer adsorption in connection with the presence of a heterogeneous pore distribution and as expressed in [57]:

$$
\frac{1}{q_{e}^{2}}=\left(\frac{B}{A}\right)-\left(\frac{1}{A}\right) \log C_{e}
$$

In a plot of $\log C_{e}$ values versus $1 / q_{e}{ }^{2}$ values, Harkins-Jura constants $A$ and $B$ are respectively obtained from slope and interception values. Higher $B$ values indicate higher contribution of physical adsorption.

\section{Evaluation of the isotherm results}

The data obtained from varying $\mathrm{Cu}$ (II) concentrations were applied to Langmuir, Freundlich, Temkin and D-R (Dubinin-Radushkevich) models. The constants related with these models are shown in Table 3.

Table 3

\begin{tabular}{|c|c|c|c|c|c|c|c|c|c|c|c|c|}
\hline \multicolumn{3}{|c|}{ Langmuir Izoterm } & \multicolumn{3}{|c|}{ Freundlich Izoterm } & \multicolumn{3}{|c|}{$\begin{array}{c}\text { Dubinin-Radushkevich } \\
\text { Izoterm }\end{array}$} & \multicolumn{4}{|c|}{ Temkin Izoterm } \\
\hline $\begin{array}{c}b \\
{\left[\mathrm{dm}^{3} / \mathrm{mg}\right]}\end{array}$ & $\begin{array}{c}q_{\max } \\
{[\mathrm{mg} / \mathrm{g}]}\end{array}$ & $R^{2}$ & $\begin{array}{c}n \\
{[-]}\end{array}$ & $\begin{array}{c}k_{f} \\
{[-]}\end{array}$ & $R^{2}$ & $\begin{array}{c}\beta \\
{\left[\mathrm{mol}^{2} / \mathrm{J}^{2}\right]}\end{array}$ & $\begin{array}{c}q_{m} \\
{[\mathrm{~mol} / \mathrm{g}]}\end{array}$ & $\begin{array}{c}E_{a} \\
{[\mathrm{KJ} / \mathrm{mol}]}\end{array}$ & $\begin{array}{c}B_{1} \\
{[\mathrm{mg} / \mathrm{g}]}\end{array}$ & $\begin{array}{c}b_{T}[\mathrm{~g} \cdot \mathrm{J} / \\
\mathrm{mg} \cdot \mathrm{mol}]\end{array}$ & $\begin{array}{c}K_{T} \\
{\left[\mathrm{dm}^{3} / \mathrm{g}\right]}\end{array}$ & $R^{2}$ \\
\hline 0.08 & 6.64 & 0.98 & 2.23 & 0.91 & 0.97 & $4 \cdot 10^{-9}$ & $3.17 \cdot 10^{-4}$ & 11.18 & 3.02 & 820.77 & 1.01 & 0.95 \\
\hline \multicolumn{3}{|c|}{ Harkins-Jura Izoterm } & & & & & & & & & & \\
\hline$\frac{A[-]}{2.15}$ & \begin{tabular}{|c|}
$B[-]$ \\
1.68
\end{tabular} & $\frac{R^{2}}{0.76}$ & & & & & & & & & & \\
\hline
\end{tabular}

Adsorption isotherm parameters

As seen in Table 3, high $R^{2}$ values were obtained from all isotherms, whereas the highest value belongs to Langmuir isotherm with 0.98 . This indicates occurrence of a homogeneous and single layered adsorption on the used sorbent.

$1 / n$ value, calculated in accordance with Freundlich equation, indicates whether the biosorption process is spontaneous. Spontaneous adsorption conditions apply in cases where $n$ values are greater than 1 [58]. In the present study $n$ value was found to be greater than 1. Accordingly, it can be inferred that almond shell is applicable for removal of copper from aqueous solutions.

Also, the activation energy $\left(E_{a}\right)$, resulting from Dubinin-Radushkevich equation, was found as 11.18 , which indicates that the adsorption occurred with ion exchange since this value falls within $8-16 \mathrm{~kJ} / \mathrm{mol}$ interval. 
$R^{2}$ was found as 0.95 for Temkin isotherm, indicating that adsorption also conforms with Temkin model. $b$ value was found as $820.77 \mathrm{~g} \cdot \mathrm{J} / \mathrm{mg} \cdot \mathrm{mol}$. This high $b$ value is an indication of endothermic adsorption [56]. In Harkin-Jura isotherm, $R^{2}$ was found as 0.76 , which is lower than all other isotherms.

\section{Adsorption thermodynamics}

Thermodynamic parameters reflect applicability and spontaneousness of a phenomenon. Thermodynamic parameters such as $\Delta G, \Delta H, \Delta S$ are calculated using equilibrium constants that vary with varying temperature [59].

Thermodynamic tests; according to the study of thermodynamics, the energy in an isolated system cannot be gained or lost when the entropy change is the driving force [60]. Thermodynamic parameters are given in equations (15) and (16):

$$
\Delta G^{0}=\Delta H^{0}-T \Delta S^{0}
$$

where: $\Delta G^{0}$ is Gibbs free energy [kJ/mol], $\Delta H^{0}$ is the enthalpy exchange [kJ/mol], $\Delta S^{0}$ is the entropy exchange $[\mathrm{kJ} / \mathrm{mol} \mathrm{K}]$.

$$
\ln K_{c}=\frac{\Delta G^{0}}{R}+\frac{\Delta H^{0}}{R T}
$$

Gibbs free energy value of adsorption process obtained under a certain temperature was calculated with $K_{c}$ using the equation $\Delta G^{0}=-R T \ln K_{c}$. Afterwards, $\ln K_{c}$ versus $1 / T$ graph was plotted (Fig. 12), $\Delta H^{0}$ and $\Delta S^{0}$ were calculated using the slope and interception point. The thermodynamic parameters found in the absorption of $\mathrm{Cu}$ (II) ions are presented in Table 4.

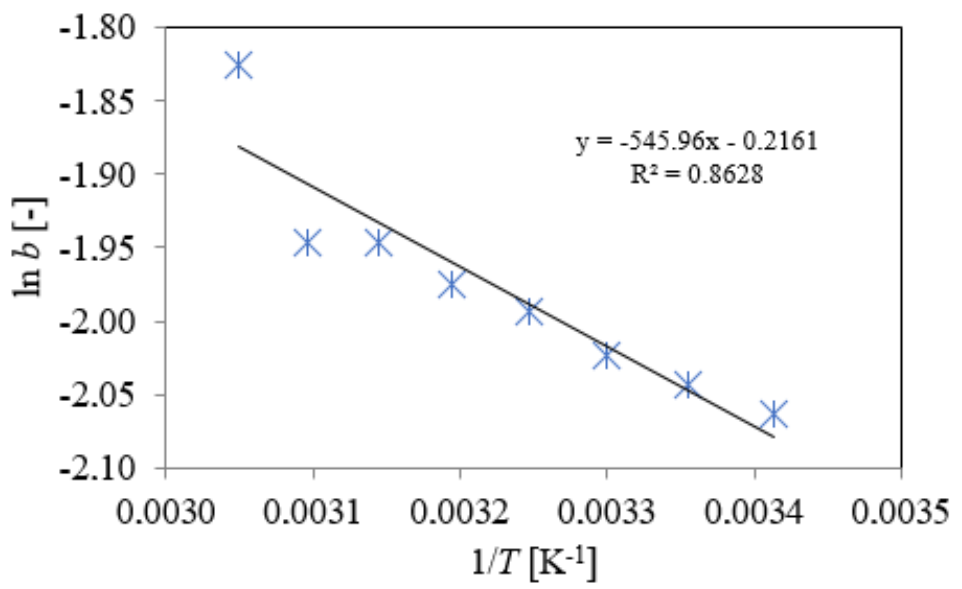

Fig. 12. Van t'Hoff graph for copper adsorption from aqueous solution with almond shell

Positive $\Delta H^{0}$ value indicates that the reaction is endothermic. Positive $\Delta G^{0}$ value indicates that the adsorption process is non-spontaneous. For the adsorption of $\mathrm{Cu}$ (II) ion, the increase in $\Delta G$ values with increasing temperature indicates that bio-sorption is more favorable at higher temperatures [61]. 
Thermodynamic parameters

\begin{tabular}{|c|c|c|c|c|}
\hline $\begin{array}{c}T \\
{[\mathbf{K}]}\end{array}$ & $\begin{array}{c}b \\
{\left[\mathrm{dm}^{3} / \mathrm{gr}\right]}\end{array}$ & $\begin{array}{c}\Delta G^{0} \\
{[\mathrm{~kJ} / \mathbf{K} \cdot \mathbf{m o l}]}\end{array}$ & $\begin{array}{c}\Delta \boldsymbol{H}^{\mathbf{0}} \\
{[\mathrm{kJ} / \mathbf{K} \cdot \mathbf{m o l}]}\end{array}$ & $\begin{array}{c}\Delta S^{0} \\
{[\mathrm{~kJ} / \mathbf{K} \cdot \mathbf{m o l}]}\end{array}$ \\
\hline 293 & 0.127 & 5.025 & \multirow{8}{*}{4.539} & \multirow{8}{*}{-0.002} \\
\hline 298 & 0.130 & 5.062 & & \\
\hline 303 & 0.132 & 5.097 & & \\
\hline 308 & 0.136 & 5.106 & & \\
\hline 313 & 0.139 & 5.139 & & \\
\hline 318 & 0.143 & 5.145 & & \\
\hline 323 & 0.143 & 5.226 & & \\
\hline 328 & 0.161 & 4.977 & & \\
\hline
\end{tabular}

Negative $\Delta S$ value is an indication of reduced randomness at solid/solution interface system during adsorption. Also, low $\Delta S^{0}$ indicates that the changes in entropy are negligible [62].

\section{Conclusions}

In the present study, almond shell was used without any pretreatment prior to the tests. The use of sorbent without any activation treatment as an attempt to reduce the cost of adsorption process constitutes one of the important aspects of the present research. Adsorption capacity $\left(q_{e}\right)$ increased with increasing $\mathrm{Ni}^{2+}$ concentrations. The greatest $q_{e}$ value for $\mathrm{Ni}^{+2}$ was observed as $5.87 \mathrm{mg} / \mathrm{g}$ in $75 \mathrm{mg} / \mathrm{dm}^{3}$. The $\mathrm{Ni}^{+2}$ ions adsorption onto almond shell was better defined by the pseudo-second-order kinetic model, for initial $\mathrm{pH}$. The highest $R^{2}$ value in isotherm studies was obtained from Langmuir isotherm $\left(R^{2}=0.98\right)$ for the inlet concentration. Gibbs energy $\left(\Delta G^{0}\right)$ values for $\mathrm{Ni}(\mathrm{II})$ ions were identified as positive (+), thus it was identified that biosorption was nonspontaneous. Positive values for biosorption enthalpy $\left(\Delta H^{0}\right)$ indicate that the system absorbed energy from surroundings (endothermic) and negative values for $\Delta S^{0}$ indicate more regular state of metal ion over the biosorbent surface. The studies in the literature on bio-sorption related with $\mathrm{Cu}^{2+}$ ions were examined and compared with the values obtained in the present study (Table 5).

Table 5

Comparison of biosorption studies performed using various biosorbent/adsorbent

\begin{tabular}{|c|c|c|}
\hline Adsorbent & Adsorption capacity [mg/g] & Reference \\
\hline Bamboo powder & 54.35 & {$[63]$} \\
\hline Sawdust & 3.60 & {$[64]$} \\
\hline Corn silk & 96.15 & {$[7]$} \\
\hline Sawdust & 3.89 & {$[65]$} \\
\hline Tobacco leaf & 14.36 & {$[11]$} \\
\hline Grass & 58.34 & {$[66]$} \\
\hline Rice hull & 59.52 & {$[67]$} \\
\hline Wheat scab & 11 & {$[68]$} \\
\hline Rice shell & 3.6 & {$[68]$} \\
\hline Coconut shell & 7.25 & {$[69]$} \\
\hline Eichhornia crassipes & 27.7 & {$[70]$} \\
\hline Almond shell & 4.67 & This study \\
\hline
\end{tabular}




\section{References}

[1] Zhou B, Wang Z, Shen D, Shen F, Wu C, Xiao R. Low cost earthworm manure-derived carbon material for the adsorption of $\mathrm{Cu}^{2+}$ from aqueous solution: Impact of pyrolysis temperature. Ecol Eng. 2017;98:189-195. DOI: 10.1016/j.ecoleng.2016.10.061.

[2] Suguna M, Reddy AS, Kumar NS, Krishnaiah A. Biosorption of manganese(II) ions from aqueous solution by glutaraldehyde cross-linked chitosan beads: Equilibrium and kinetic studies. Adsorp Sci Technol. 2010;28:213-219. DOI: 10.1260/0263-6174.28.3.213.

[3] Feng NC, Guo XY, Liang S. Adsorption study of copper(II) by chemically modified orange peel. J Hazard Mater. 2009;164:1286-1292. DOI: 10.1016/j.jhazmat.2008.09.096.

[4] Anırudhan TS, Rajı C, Shubha KP. Immobilization of heavy metals from aqueous solutions using polyacrylamide grafted hydrous tin(IV) oxide gel having carboxylate functional groups. Water Res. 2001;35:300-310. DOI: 10.1016/S0043-1354(00)00234-7.

[5] Kocadagistan E, Bascı N, Kocadagistan B. Biosorption of copper(II) from aqueous solutions by wheat shell. Desalination. 2004;164:135-140. DOI: 10.1016/S0011-9164(04)00172-9.

[6] Hashemian S, Mirshamsi M. Kinetic and thermodynamic of adsorption of 2-picoline by sawdust from aqueous solution. J Industrial Eng Chem. 2012;18(6):2010-2015. DOI: 10.1016/j.jiec.2012.05.020.

[7] Yu H, Pang J, Ai T, Liu L. Biosorption of $\mathrm{Cu}^{2+}, \mathrm{Co}^{2+}$ and $\mathrm{Ni}^{2+}$ from aqueous solution by modified corn silk: Equilibrium, kinetics, and thermodynamic studies. J Taiwan Inst Chem Eng. 2016;62:21-30. DOI: 10.1016/j.jtice.2016.01.026.

[8] Ding Y, Jing D, Gong H, Zhou L, Yang X. Biosorption of aquatic cadmium(II) by unmodified rice straw. Bioresour Technol. 2012;114:20-25. DOI: 10.1016/j.biortech.2012.01.110.

[9] Sundaram MN, Sivakumar S. Use of indian almond shell waste and groundnut shell waste for the removal of azure a dye from aqueous solution. J Chem Pharm Res. 2012;4(4):2047-2054. http://www.jocpr.com/articles/ use-of-indian-almond-shell-waste-and-groundnut-shell-waste-for-the-removal-of-azure-a-dye-from-aqueoussolution.pdf.

[10] Abdessalem O, Mourad B, Najwa A. Preparation, modification and industrial application of activated carbon from almond shell. J Ind Eng Chem. 2013;19(6):2092-2099. DOI: 10.1016/j.jiec.2013.03.025.

[11] Çekim M, Yıldız S, Dere T. Biosorption of copper from synthetic waters by using tobacco leaf: equilibrium, kinetic and thermodynamic tests. J Environ Eng Landscape Manage. 2015;23(03):172-182. DOI: 10.3846/16486897.2015.1050398.

[12] Sahranavard M, Ahmadpour A, Doosti MR. Biosorption of hexavalent chromium ions from aqueous solutions using almond green hull as a low-cost biosorbent. Eur J Sci Res. 2011;58(3):392-400. DOI: $10.1155 / 2014 / 670249$

[13] Deniz F. Dye removal by almond shell residues: Studies on biosorption performance and process design. Materials Sci Eng. 2013;C 33:2821-2826. DOI: 10.1016/j.msec.2013.03.009.

[14] Ardejani FD, Badii K, Yousefi Limaee N, Shafaei SZ, Mirhabibi AR. Adsorption of Direct Red 80 dye from aqueous solution onto almond shells: Effect of $\mathrm{pH}$, initial concentration and shell type. J Hazard Mater. 2008;151:730-737. DOI: 10.1016/j.jhazmat.2007.06.048.

[15] Mehrasbi MR, Farahmandkia Z, Taghibeigloo B, Taromi A. Adsorption of lead and cadmium from aqueous solution by using almond shells. Water Air Soil Pollut. 2009;199:343-351. DOI: 10.1007/s11270-008-9883-9.

[16] Duran C, Ozdes D, Gundogdu A, Senturk HB. Kinetics and isotherm analysis of basic dyes adsorption onto almond shell (Prunus dulcis) as a low cost adsorbent. J Chem Eng Data. 2011;56:2136-2147. DOI: 10.1021/je101204j.

[17] Fathi MR, Asfaram A, Hadipour A, Roosta M. Kinetics and thermodynamic studies for removal of acid blue 129 from aqueous solution by almond shell. J Environ Health Sci Eng. 2014;12:62. DOI: 10.1186/2052-336X-12-62.

[18] Hashemian S, Salari K, Yazdi ZA. Preparation of activated carbon from agricultural wastes (almond shell and orange peel) for adsorption of 2-pic from aqueous solution. J Industrial Eng Chem. 2014;20:1892-1900. DOI: 10.1016/j.jiec.2013.09.009.

[19] Wang XS, Qin Y. Equilibrium sorption isotherms of $\mathrm{Cu}^{2+}$ on rice bran. Process Biochem. 2005;40:677-680. DOI: $10.1016 /$ j.procbio.2004.01.043.

[20] Ajmal M, Khan AH, Ahmad S, Ahmad A. Role of sawdust in the removal of copper(II) from industrial wastes. Water Res. 1998;32:3085-309. DOI: 10.1016/S0043-1354(98)00067-0.

[21] Goyal M, Rattan VK, Aggarwal D, Bansal RC. Removal of copper from aqueous solutions by adsorption on activated carbons. Colloids Surf. 2001;190:229-238. DOI: 10.1016/S0927-7757(01)00656-2. 
[22] Srivastava SK, Tyagi R, Pant N. Adsorption of heavy metal ions on carbonaceous material developed from the waste slurry generated in local fertilizer plants. Water Res. 1989;23(9):1161-1165. DOI: 10.1016/0043-1354(89)90160-7.

[23] El-Kamash AM, Zaki AA, Abed El Geleel M. Modeling batch kinetics and thermodynamics of zinc and cadmium ions removal from waste solutions using synthetic zeolite A. J Hazard Mater. 2005;127:211-220. DOI: 10.1016/j.jhazmat.2005.07.021.

[24] Paduraru C, Tofan L, Teodosiu C, Bunia I, Tudorachi N, Toma O. Biosorption of zinc(II) on rapeseed waste: equilibrium studies and thermogravimetric investigations. Process Saf Environ Prot. 2015;94:18-28. DOI: 0.1016/j.psep.2014.12.003.

[25] Lee S, Kwon O, Yoo K, Alorro RD. Removal of $\mathrm{Zn}$ from contaminated sediment by $\mathrm{FeCl}_{3}$ in $\mathrm{HCl}$ solution. Metals. 2015;5:1812-1820. DOI: 10.3390/met5041812.

[26] Giwa AA, Abdulsalam KA, Wewers F, Oladipo MA. Biosorption of acid dye in single and multidye systems onto sawdust of locust bean (Parkia biglobosa) tree. J Chem. 2016; Article ID 6436039. DOI: $10.1155 / 2016 / 6436039$.

[27] Aljeboreea AM, Alshirifib AN, Alkaim AF. Kinetics and equilibrium study for the adsorption of textile dyes on coconut shell activated carbon. Arab J Chem. 2014. DOI: 10.1016/j.arabjc.2014.01.020.

[28] Maheshwari U, Mathesan B, Gupta S. Efficient adsorbent for simultaneous removal of $\mathrm{Cu}(\mathrm{II}), \mathrm{Zn}$ (II) and $\mathrm{Cr}(\mathrm{VI})$ : Kinetic, thermodynamics and mass transfer mechanism. Process Saf Environ Protect. 2015;98:198-210. DOI: 10.1016/j.psep.2015.07.010.

[29] Subramani SE, Thinakaran N. Isotherm, kinetic and thermodynamic studies on the adsorption behaviour of textile dyes onto chitosan. Process Saf Environ Protect. 2017;106:1-10. DOI: 10.1016/j.psep.2016.11.024.

[30] Lagergren S. Zur theorie der sogenannten adsorption geloster stoffe. Kungliga Svenska Vetenskapsakademiens. (On the theory of the so-called adsorption of dissolved substances. Kungliga Svenska Vetenskaps Academy). Handlingar Band. 1898;24(4):1-39.

[31] Zhang J, Cai D, Zhang G, Cai C, Zhang C, Qiu G, et al. Adsorption of methylene blue from aqueous solution onto multiporous palygorskite modified by ion beam bombardment: Effect of contact time, temperature, $\mathrm{pH}$ and ionic strength. Appl Clay Sci. 2013;83-84:137-143. DOI: 10.1016/j.clay.2013.08.033.

[32] Ho YS, McKay G. The kinetics of sorption of basic dyes from aqueous solution by sphagnum moss peat. Can J Chem Eng. 1998;76(4):822-827. DOI: 10.1002/cjce.5450760419.

[33] Weber WJ, Morris JC. Kinetics of adsorption on carbon from solutions. Amer Soc Civil Engineers. 1963;89:31-60.

[34] Murugesan A, Ravikumar L, Selva Bala BV, Kumar SP, Vidhyadevi T, Dnesh Kirupha S, et al. Removal of $\mathrm{Pb}$ (II) $\mathrm{Cu}$ (II) and $\mathrm{Cd}$ (II) ions from aqueous solution using polyazomethineamides: equilibrium and kinetic approach. Desalination. 2011;271:199-208. DOI: 10.1016/j.desal.2010.12.029.

[35] Hameed BH. Equilibrium and kinetic studies of methyl violet sorption by agricultural waste. J Hazard Mater. 2008;154:204-212. DOI: 10.1016/j.jhazmat.2007.10.010.

[36] Wu FC, Tseng RL, Juang RS. Characteristics of Elovich equation used for the analysis of adsorption kinetics in dye chitosan systems. Chem Eng J. 2009;150:366-373. DOI: 10.1016/j.cej.2009.01.014.

[37] Bangham DH, Burt FP. The behavior of gases in contact with glass surfaces. Proc Royal Soc London. Ser A: Math Phys Character. 1924;105:481-488. http://www.jstor.org/stable/94228.

[38] Fan T, Liu Y, Feng B, Zeng G, Yang C, Zhou M, et al. Biosorption of cadmium(II), zinc(II) and lead(II) by Penicillium simplicissimum: Isotherms, kinetics and thermodynamics. J Hazard Mater. 2008;160:655-661. DOI: $10.1016 /$ j.jhazmat.2008.03.038.

[39] Nuhoglu Y, Malkoc E. Thermodynamic and kinetic studies for environmentally friendly Ni(II) biosorption using waste pomace of olive oil factory. Bioresour Technol. 2009;100:2375-2380. DOI: 10.1016/j.biortech.2008.11.016.

[40] Joo JH, Hassan SHA, Oh SE. Comparative study of biosorption of Zn2 by Pseudomonas aeruginosa and Bacillus cereus. Int Biodeterioration Biodegrad. 2010;64:734-741. DOI: 10.1016/j.ibiod.2010.08.007.

[41] Dotto GL, Pinto LAA. Analysis of mass transfer kinetics in the biosorption of synthetic dyes onto Spirulina platensis nanoparticles. Biochem Eng J. 2012;68:85-90. DOI: 10.1016/j.bej.2012.07.010.

[42] Cardoso NF, Lima EC, Royer B, Bach MV, Dotto GL, Pinto LAA, Calvete T. Comparison of Spirulina platensis microalgae and commercial activated carbon as adsorbents for the removal of reactive red 120 dye from aqueous effluents. J Hazard Mater. 2012;241-242:146-153. DOI: 10.1016/j.jhazmat.2012.09.026.

[43] Kavitha D, Namasivayam C. Recycling coir pith, an agricultural solid waste, for the removal of procion orange from wastewater. Dyes Pigm. 2007;74:237-248. DOI: 10.1016/j.dyepig.2006.01.040.

[44] Dursun YA. A comparative study on determination of the equilibrium, kinetic and thermodynamic parameters of biosorption of copper(II) and lead(II) ions onto pretreated Aspergillus niger. Biochem Eng. 2006;28:187-195. DOI: 10.1016/j.bej.2005.11.003. 
[45] Yanping J, Yunying W, Julin C, Yunhai W. Adsorption behavior of Cr(VI), Ni(II), and Co(II) onto zeolite 13x. Desalin Water Treat. 2015;54(2):511-524. DOI: 10.1080/19443994.2014.883333.

[46] Brunader S. The Adsorption of Gases and Vapors. Vol. 1. London: Oxford University Press; 1942.

[47] Wang S, Li H. Dye adsorption on unburned carbon: Kinetics and equilibrium. J Hazard Mater. 2005;126:71-77. DOI: 10.1016/j.jhazmat.2005.05.049.

[48] Langmuir I. The adsorption of gases on mica and platinum. J Am Chem Soc. 1918;40:1361-1403.

[49] Freundlich H. Colloid and Capillary Chemistry. London: Metheun; 1926.

[50] Thomas JM, Thomas WJ. Introduction to the Principles of Heterrogeneous Catalysis. New York: Academic Press; 1967.

[51] Dubinin MM, Radushkevich LV. Proc Acad Sci Physico Chem. 1947;550:331-340.

[52] Hasany SM, Chaudhary MH. Sorption potential of Hare River sand for the removal of antimony from acidic aqueous solution. Appl Radiation Isotopes. 1996;47:467-471. DOI: 10.1016/0969-8043(95)00310-X.

[53] Onyang MS, Kojima Y, Aoyi O, Bernardo EC, Matsuda H. Adsorption equilibrium modeling and solution chemistry dependence of fluoride removal from water by trivalent-cation-exchanged zeolite F-9. J Colloid Interface Sci. 2004;279:341-350. DOI: 10.1016/j.jcis.2004.06.038.

[54] Temkin MJ, Phyzev V. Recent modifications to Langmuir isotherms. Acta Physicochim USSR. 1940;12:217-222.

[55] Aharoni C, Ungarish M. Kinetics of activated chemisorption. Part 2-Theoretical models. J Chem Soc Faraday Trans. 1977;73:456-464. DOI: 10.1039/F19777300456.

[56] Sekar M, Sakthi V, Rengaraj S. Kinetics and equilibrium adsorption study of lead(II) onto activated carbon prepared from coconut shell. Colloid Interface Sci. 2004;279:307-313. DOI: 10.1016/j.jcis.2004.06.042.

[57] Harkins WD, Jura G. Surfaces of Solids. XIII. A Vapor Adsorption Method for the Determination of the Area of a Solid without the Assumption of a Molecular Area, and the Areas Occupied by Nitrogen and Other Molecules on the Surface of a Solid. J Chem Phys. 1944;66(8):1366-1373. DOI: 10.1021/ja01236a048.

[58] Hameed B, Mahmoud D, Ahmad A. Sorption of basic dye from aqueous solution by pomelo (Citrus grandis) peel in a batch system. Colloids Surfaces A: Physicochem Eng Aspects. 2008;316(1):78-84. DOI: 10.1016/j.colsurfa.2007.08.033.

[59] Aksu Z, Kabasakal E. Batch adsorption of 2,4-dichlorophenoxy-acetic acid (2,4-D) from aqueous solution by granular activated carbon. Sep Purif Technol. 2004;35:223-240. DOI: 10.1016/S1383-5866(03)00144-8.

[60] Shah J, Jan MR, Haq A, Zeeshan M. Equilibrium, kinetic and thermodynamic studies for sorption of Ni(II) from aqueous solution using formaldehyde treated waste tea leaves. J Saudi Chem Soc. 2015;19(3):301-310. DOI: 10.1016/j.jscs.2012.04.004.

[61] Kulkarni RM, Shetty KV, Srinikethan G. Cadmium(II) and nickel(II) biosorption by Bacillus laterosporus (MTCC 1628). J Taiwan Inst Chem Engineers. 2014;45(4):1628-1635. DOI: 10.1016/j.jtice.2013.11.006.

[62] Ahmad MF, Hayda S, Quraishi TA. Enhancement of biosorption of zinc ions from aqueous solution by immobilized Candida utilis and Candida tropicalis cells. Int Biodeterioration Biodegrad. 2013;83:119-128. DOI: 10.1016/j.ibiod.2013.04.016.

[63] Argun ME, Dursun S, Ozdemir C, Karatas M. Heavy metal adsorption by modified oak sawdust: thermodynamics and kinetics. J Hazard Mater. 2007;141:77-85. DOI: 10.1016/j.jhazmat.2006.06.095.

[64] Shukla SR, Pai RS. Adsorption of $\mathrm{Cu}(\mathrm{II}), \mathrm{Ni}(\mathrm{II})$ and $\mathrm{Zn}$ (II) on dye loaded ground- nut shells and sawdust. Sep Purif Technol. 2005;43:1-8. DOI: 10.1016/j.seppur.2004.09.003.

[65] Putra WP, Kamari A, Yusoff SNM, Ishak CF, Mohamed A, Hashim N, et al. Biosorption of Cu(II), Pb(II) and $\mathrm{Zn}$ (II) ions from aqueous solutions using selected waste materials: Adsorption and characterisation studies. J Encapsulation Adsorption Sci. 2014;4:25-35. DOI: 10.4236/jeas.2014.41004.

[66] Hossain MA, Ngo HH, Guo WS, Setiati T. Adsorption and desorption of copper(II) ions onto garden grass. Bioresour Technol. 2012;121:386-395. DOI: 10.1016/j.biortech.2012.06.119.

[67] Osman HE, Badwy RK, Ahmad HF. Usage of some agricultural by-products in the removal of some heavy metals from industrial wastewater. J Phytol. 2010;2:51-62. http://scienceflora.org/journals/index.php/jp/ article/viewFile/2100/2079.

[68] Qian Q, Mochidzuki K, Fujii T, Sakoda A. Removal of copper from aqueous solution using iron containing adsorbents derived from methane fermentation sludge. J Hazard Mater. 2009;172:1137-1144. DOI: 10.1016/j.jhazmat.2009.07.107.

[69] Acheampong MA, Pakshirajan K, Annachhatre AP, Lens PNL. Removal of Cu(II) by biosorption onto coconut shell in fixed-bed column systems. J Ind Eng Chem. 2013;19:841-848. DOI: 10.1016/j.jiec.2012.10.029.

[70] Komy ZR, Abdelraheem WH, Ismail NM. Biosorption of $\mathrm{Cu} 2+$ by Eichhornia crassipes: physicochemical characterization, biosorption modeling and mechanism. J King Saud Univ. 2013;25:47-56. DOI: 10.1016/j.jksus.2012.04.002. 